\title{
Babu wa Loliondo-Healing the Tensions between Tanzanian Worlds
}

\author{
Mika Vähäkangas \\ Center for Theology and Religious Studies \\ P.O. Box 201 \\ 22100 Lund \\ Mika.vahakangas@teol.lu.se
}

\begin{abstract}
Tanzanian Ambilikile Mwasapila aka Babu wa Loliondo, a retired Lutheran countryside pastor, suddenly became the most visible media personality and healer in East Africa for half a year in 2011. He had received dreams in which God provided him with the recipe for a herbal medicine that would heal all maladies. Lutheran bishops who had all but abandoned the elderly pastor in his former remote mission field eagerly approved his ministry, while reception in Charismatic churches was mixed. After initial suspicion, the government strongly backed him, and the national research hospital vaguely endorsed the medicine, which is essentially the same as traditional medicine in several ethnic groups. Thus, in this ministry modern scientific, Christian, and traditional worldviews suddenly corresponded, thereby easing the tensions between the three lifeworlds of Tanzanian Christians. After the deaths of several HIV-positive patients who had abandoned antiretroviral (ARV) drugs, the magic of the healer vanished.
\end{abstract}

\section{Keywords}

Babu wa Loliondo - pluralistic medicine - faith healing - herbalism - ritual - African Christianity

\section{Introduction}

We stand at a tiny shelter of sticks and plastic by a roadside in a remote Tanzanian village. The shelter is like many roadside stalls where women 
sell agricultural produce, except that this one is adorned with ropes and chains allegedly used to bind the insane who have been healed here. Today there are a mere nine of us to be treated by the retired Lutheran pastor Mwasapila with his two helpers. Only the ropes and chains remind us of the multitudes that have visited this spot in the past. All of us are foreigners: me-a European with my small voice recorder, six Southern Sudanese in their Western secondhand clothes, and two traditionally clad Kenyan Maasai. Because there is no common language, I find myself interpreting from Kiswahili into English and a young Sudanese man continues the chain of translation from English into Dinka. The air is full of pious expectation. The small, modestly clad, and soft-spoken healer explains how the medicine heals all diseases, but with some it will take time. He lets the customers pose questions, which the Sudanese are eager to do: "Will this heal my feet? Will you also pray for Sudan?" After a prayer requesting healing and thanking God, plastic mugs are distributed to us. We are shy to start drinking. I struggle to swallow this slightly bitter concoction. A young Sudanese woman in a worn-out Shakira t-shirt looks especially moved. The simple session is over after the assistant has collected the mugs as well as a dollar or 100 Kenyan shillings from each of us. I remain chatting with the Sudanese. An elderly man with his walking stick happily announces that his feet feel stronger already. (4 February 2012, diary; Babu kikombe)

The fact that hundreds of thousands of patients, Tanzanians as well as foreign, were willing to make the tedious journey to the remote village of Samunge to be healed by Rev. Ambilikile Mwasapila points on the one hand to the failure of biomedical services in Africa, but on the other it also reflects some deeper cultural longing that biomedicine is not able to address. This is reflected in the request by the elderly Sudanese not only for the healing of his feet but also of his war-torn land. This article describes and analyses the case of Rev. Mwasapila, aiming to give an account of a healing ministry that has not previously been dealt with except in a few short newspaper articles and a Kiswahili booklet that contains a number of errors and is mostly directed at propagating the theological position of the author (Mwakalinga 2011).

The article begins by describing the context of the village of Samunge. Rev. Mwasapila's life story is then discussed in relation to other healers' life stories. This is followed by a description of his healing ministry, the public discourse that surrounds him, and the power relations revealed by the debate. The remainder of the article analyses the reasons for his instant and huge success as well as its demise. The theoretical starting point of the article is medical 
pluralism, which leads into considering the cultural categories in the lives of Tanzanian Christians as portrayed through the reception of Rev. Mwasapila's healing ministry.

Introduced by colonial authorities and missionaries, biomedicine created a situation of medical pluralism in Tanzania in which traditional ways of healing became measured against the yardstick of Western medicine (Langwick 2011; Feierman 2000). Eventually, through the Witchcraft Ordinance of 1928, the colonial authorities imposed an artificial division between pure herbalism and 'witchcraft', i.e., healing involving spiritual dimensions. The colonial approach depicted traditional healers as either charlatans or witches. This discourse continues even today in both government and ecclesiastic circles (Langwick 2011; Green 2003) even though the government has strived to gain control over the traditional medical practitioners, which has led to their gradual and partial approval. Colonial authorities thus attempted to create an exclusivist medical system while later developments have opened it up toward a more tolerant medical pluralism. However, one cannot maintain that there is a common field of medicine but rather that there are parallel medical worlds that compete, overlap, and clash. ${ }^{1}$ This article deals with Christian faith healing as a way of overcoming this division when the herbal element is included in the practice. Christian faith healing can be regarded as a response to the exclusion of the spiritual element in healing when the traditional ways combining the spiritual and the material are despised and marginalised. Babu's healing reintroduced the material herbal element into Christian faith healing. As a result, the forces of the cultural categories at play - traditional, missionary Christian, and modern - were interwoven in a manner that briefly functioned as a solution to these cultural tensions and complexities.

Material for the article was collected on a trip to map out the possibilities and need for larger research on Rev. Mwasapila's healing ministry, during which I spent four hectic days in Samunge, a village that was familiar to me from previous visits before the 'jam', as the villagers called the rush to be healed. However, I did not know Rev. Mwasapila (Babu) previously. My data eventually consisted of ten recordings with Babu, nine very loosely structured deep interviews or interview fragments (recorded snippets from discussions after interviews - always with Babu's approval), as well as a forty-minute audio recording of a session in which the medicine was distributed. The total length of the interviews was three hours. In addition, I had hours of informal discussions with Babu, his assistants, and villagers. I also conducted two interviews with Babu's first patient and an interview with an evangelist in the village. I observed the devotion of Babu's team of volunteers and their work to prepare a centre for the ministry. I also participated in dimensions of daily life as well 
as the life of villagers, actively engaging them in discussions. In addition to the material from Samunge, I discussed the healing ministry informally with dozens of Tanzanians outside the village during a two-week period, most of whom have been old friends and colleagues for up to a quarter of a century. All of them had obtained the medicine. As a result, I had about seventy handwritten pages of field diary.

In addition to personal communication, this article is based on a systematic browsing of the Tanzanian leading daily Swahili newspapers Nipashe and Majira and the weeklies Rai, Mwanahalisi, and Raia mwema, as well as occasional browsing of the Daily News and The Guardian. This sample covers only a fraction of Tanzanian dailies and weeklies, but can be considered representative since the Kiswahili papers in particular are popular and do not have any major preference for reporting on religious issues. Additionally, I conducted extensive Internet searches. ${ }^{2}$

I have been in contact with the Evangelical Lutheran Church of Tanzania (ЕLCT) since 1990 in various ways, most visibly as a lecturer of theology in the leading church-run university, Makumira University College. Therefore, even if not personally known to Babu I was not a complete stranger either, being, for example, a former teacher of the pastor who followed Babu in the village. Rather, my position could be described as a marginal insider vis-à-vis the ELCT. Therefore it was natural that I served as the interpreter from Swahili to English for Babu's foreign patients while I was both a patient myself and a professor visiting the scene. My travel companion and former student, Rev. Philemon Mollel, also contributed to the creation of the feeling of togetherness, being a pastoral colleague of Babu from the same diocese as well as a compatriot. This position opened doors that would perhaps not be opened to an outsider and yet allowed me greater freedom to ask critical questions because I was not a 'true' insider.

Healing is a sought-after commodity in the religious market of Tanzania, which is largely dominated by four groups: traditional healers; Muslim healers; ${ }^{3}$ the so-called spiritual churches; ${ }^{4}$ and biomedicine in governmental, private, and NGO-run hospitals and dispensaries (see, e.g., Feierman 1985). The category of traditional healers conflates practitioners of various kinds who base their professional credibility on African pre- or antimodern categories. The concept 'traditional' (kienyeji) is a loaded term in Tanzania, and is used either in a positive or pejorative sense depending on the occasion. Churches and other faith-based organizations provide a considerable part of Tanzanian services in biomedicine. ${ }^{5}$ This medical pluralism is not only an African phenomenon but the level of pluralism in Africa tends to be greater than in many other parts of the world, partly because of the relative weakness of the 
biomedical services but also because of the strength of several other competing healing paradigms. ${ }^{6}$ It is therefore an indication of competing patterns of meaning or value structures in Tanzanian society (see Lindhardt 2010). Because this article deals with a Lutheran healer, it is worth examining the roots of Tanzanian Charismatic healing.

The East African Revival that began in 1928 (Munga 1998) served as the seedbed for Charismatic groups and phenomena while remaining within the historic churches, mainly the Lutheran, Anglican, and Moravian but also the Catholic Church (see Munga 1998; Sendoro 200o). However, while the revival had a profound effect on these churches, the revivalist meetings often remained separate or marginal in church life. Faith healing would eventually become the hallmark of the spiritual churches that could be considered hybrids of traditional African spirituality, the regional East African Revival, and international Pentecostal and Charismatic influences. Some of the leaders and preachers of the spiritual churches or Charismatic parachurch organizations or ministries come from an East African Revival background. Charismatic renewal was thus first contained within the historic churches through the East African Revival; recently the current of charismatic revivalism has begun to flow outside these churches, though charismatically oriented pastors and priests are to be found in almost every denomination. The greatest exception to this shift of gravity of charismatic phenomena from the historic churches is Ambilikile Mwasapila, popularly known as Babu wa Loliondo, or the Grandfather of Loliondo after the district where he resides, who became the comet of African prayer healing in early 2011. This retired Lutheran missionary pastor captured the public imagination nationally and also internationally for a period of about half a year, drawing huge crowds to his remote village of Samunge in northern Tanzania.

\section{The Sonjo Area as an Ecclesial Backwater}

Tanzanian Lutherans have been missionizing the northern Tanzanian Sonjo, or Batemi, since 1947. The Catholics made their appearance in the 1950s and the Pentecostal presence began in the 1990 s. $^{7}$ In spite of all this mostly Tanzanian effort to Christianize the Sonjo, the result must be regarded as meagre in terms of numbers. In the absence of any reliable statistics, one can estimate that the number of baptized Christians among the Sonjo remained at about 10 percent before the Babu wa Loliondo heyday, while the number of active Christians was just a fraction of 1 percent. The traditional religion retained its hegemony in the area. Only a limited number of women and children participated in church 
activities in the most Christian-influenced adjacent villages of Samunge and Digodogo (Vähäkangas 2008b).

The Sonjo villages are agricultural, relying mostly on irrigation water from permanent springs. They are also remarkably isolated, partly because of a lack of proper roads in the corner west of Ngorongoro and south of Kenya. Additionally, the surrounding Maasai are traditional nemeses, thereby contributing to the sense of isolation (see, e.g., Gray 1963). The Christian groups were furthermore marginalized in the Sonjo communities, thereby making them vulnerable and particularly isolated (Vähäkangas 2008a).

The Lutheran mission was comprised of Tanzanian pastors and evangelists as missionaries who usually spent up to a couple of years in the area (Parsalaw 1999; Nathan, Eliufoo and Salema 1952). Eventually the Lutheran Church was able to recruit and train two local pastors, both of whom, however, soon died (Iversen 1981; Iversen 1984). A new missionary pastor had to be recruited after their deaths. This was not easy because the missionaries largely had to fend for themselves far away from home in a partly hostile community. The salary was nominal, and receiving it was difficult because of the miserable bus connections. The area was not within reach of electricity and later, when most of the rest of Tanzania was being serviced by mobile phone networks, the Sonjo area lagged behind. Therefore it was with a sigh of relief that the pastors sitting quietly in the meeting of Lutheran diocese of the Arusha Region heard Rev. Mwasapila volunteer to work among the Sonjo. ${ }^{8}$ His ministry in Samunge village began in 1989 (Babu 2).

\section{The Making of a Healer}

Babu remains an enigmatic person to many, with plenty of conflicting information on his life. In the following, I have constructed his life story on the basis of my interviews with him as well as published material and hearsay. I verified the information from the latter two types of sources with Babu. Because he is not much of a storyteller, least of all about himself, I have had to make use of these other sources as well.

Born in 1936 in Ibililo, a village in the Konde area of the Mbeya Region of southern Tanzania, and orphaned as a young boy, Ambilikile Mwasapila had to learn early to fend for himself. ${ }^{9}$ As a teenager he migrated to northern Tanzania in search of work, and eventually learned to build houses. In due time he would take the long route to priesthood through studying to become an evangelist, then working and studying to become a pastor. He took these steps toward an ecclesial career in the Northern Tanzanian town of Babati where he had 
settled in 1965 (Babu 2). Staying true to the religious calling was not easy. Life must have been hard with the tiny and unreliable salary from the church-the Lutheran dioceses' financial situation was and is often tough, and the first to go without salaries are usually those lowest in the hierarchy. Being an ethnic outsider in Northern Tanzania and with only the minimum educational requirements to be a pastor, having been educated only in a Bible school, he was not destined to become one of the top-tier leaders of his diocese so there were no major incentives in view.

Babu recounts that while he was still working in Babati he faced a serious temptation to enter the gem business in the Mererani mining area that produces highly desired blue Tanzanite gemstones. His friend planned to do so, and the opportunity was also open to him. As he was pondering his decision, he had a dream in which he and his friend were collecting the gems. The gems began to burn his hands, whereas his friend had no such problems. The pastor understood that this was a message from God telling him to abstain from the gem trade and remain true to his pastoral calling. It seems that Babu considers this first divine dream, resulting in his overcoming temptation, as an opening of a channel to God and he has since received many such messages in dreams (Babu 2). Today if he wants to ask something of God, he expresses the question in evening prayer and the answer is soon available (Babu 2). The description of the temptation to reject the pastoral call has a Biblical prototype in Jonah, but is also similar to several African religious figures, not least Simon Kimbangu, the Congolese prophet behind the founding of the Kimbanguist Church (Martin 1976), and the revivalist leader Daniel Ndoundou of the Evangelical Church in Congo (Brazzaville) who did not launch his own church but remained in this mainline Protestant denomination (Åhman 2013).

Babu eventually settled in Samunge in 1989 to serve as a missionary pastor, though it was a move that was not motivated by divine revelation. From this point on he would be out of sight in an almost-forgotten mission field, but alongside the official churchly calling there was another vocation brewing. In January 1991 he received yet another dream in which a woman unknown to him came before him and God's voice told him, 'Give her that medicine of yours and she will be cured of AIDs'. ${ }^{10}$ He had no idea what this meant. The strange dream left him perplexed while he continued with his pastoral ministry.

In 2002 this short, balding, modest pastor retired; to the surprise of many, the former missionary remained in Samunge, only occasionally visiting his family in Babati where they had been living for all these years. Babati is located about 300-400 km from Samunge, the first sections being practically off road and public transport almost nonexistent. The reason for this surprising decision was that, according to Babu, he had received another message from God 
telling him that he still had a good deal to do in Samunge (Babu 2). He then disappeared even more deeply into oblivion, apart from an occasional pension payment coming from the diocese, and the new Samunge pastor participated in the diocesan pastors' meetings. The pension was initially Tsh 10,00o or about five pounds sterling per month; though this amount was later doubled twice, twenty pounds per month is not enough to sustain a person even in a country with a low cost of living like Tanzania. Babu had to move away from the modest but, in local terms, proper pastor's house in the church compound and settle in a tiny mud hut offered by a friendly local Christian. He sustained himself as a skilled construction worker, thus returning to his early occupation (Babu 5; FD-informal communication).

In this uncertain existence the pastor emeritus continued to receive dreams, but it was only in 2009 that events began to unfold. While waiting for choir rehearsal to begin in the Samunge church, he again saw the AIDS-infected woman from his dream of eighteen years earlier. The following night he had a dream in which a person offered him two roots, one in each hand, and he understood that this was the key to the medicine. As yet he had no recipe and no dosage, but he received those shortly afterward: in a dream he was shown a bucket full of red/brown liquid by which he understood that the roots needed to be cooked in water. Beside the bucket there was a cup to measure the medicine. A quite ordinary-looking plastic cup had appeared in the pastor's home, and no one was able to tell him where it had come from. He understood that all of the pieces of the puzzle had found their places and he was able to produce the first round of medicine, which he gave to the woman from the dream. This was in May 2009 (Babu 2; Mwakalinga 2011). She perceived herself as cured of AIDS, threw away her ARVs and went to be checked. She told me that the doctors were surprised to find no trace of the virus (interview with Mama Upendo, 4 February 2012). Provided that her account is correct, she had lived a couple of years without ARVs at the time of the interview; one would have expected the disease to have proceeded to a stage in which symptoms would be visible. This was not the case with Mama Upendo - her skin was in good shape and she had no other signs of the illness.

After almost two decades of uncertainty about his new calling, it was now clear to Babu what God wanted from him. What is noteworthy is that Babu's account of his calling bears striking similarities to life stories recounted by traditional healers: sickness being a part of the calling process resonates with the path of becoming a healer in many traditions in which the ancestral spirits or God call through such tribulation (Langwick 2011; Stroeken 2010). This is not surprising because the lives of many African Christian leaders are true incarnations of the fusion of African traditions and Christianity. Additionally, a liminal 
period of uncertainty is a recurring theme in life stories of this kind. In many stories concerning the calling of founders of African Instituted Churches, this period involves a severe sickness or even death or near-death situations, as exemplified in the narratives of, among others, Kimpa Vita, Johane Masowe, Alice Lenshina Mulenga, and Alice Lakwena (Thornton 1998; Wolanin 1993; Hinfelaar 1991; Allen 1991; Behrend 1999). Babu did not become sick, but his harsh life situation as a pensioner working on construction sites and living in a tiny mud hut could well be likened to the tribulations of the prophet-healers who underwent sicknesses or (near-)death experiences. Thus the pattern of his calling conforms to an extent to equivalent religious figures' calling and is strongly on the continuum between Christianity and African traditions.

\section{A Voice in the Wilderness}

News of the first healing began to spread like concentric ripples in water. At first it was passed by word of mouth, with the first newspaper articles generally beginning to be seen in February 2011, by which time Babu's ministry was already a major phenomenon. By March Babu wa Loliondo had become daily news covered in several newspapers, often making the headlines. Until June no other subject gained even a fraction of the media coverage dedicated to Babu: 'Forget about politics! Forget about football! Forget about corruption! One topic above all has dominated conversations in Tanzania during recent weeks - the tens of thousands of people that have been flocking to Samunge village ... to try a 'miracle cure' being dispensed there by ... Pastor Ambilikile Mwasapila' (Tanzanian Affairs 1 May 2011).

Eventually sick people from all around East Africa and beyond flocked to Samunge by the thousands. Since the place is remote and serviced only by bad roads or tracks, the tourism industry of the Serengeti and Ngorongoro game parks almost came to a standstill since all available four-wheel drives were used for trips to Samunge. Airline charter companies based in Nairobi shifted their business to Arusha airport to create an airlift to the airstrip close to Samunge (Ubwani 2011). Famous Tanzanian politicians rushed to get the cure, and there were wild rumours about who among the highest-level leaders had been there incognito. Journalists, including foreign broadcasting corporations, crowded to the spot. Car queues allegedly reached up to fifty kilometres in length, and people waited for days to get to the healer (Philemon 2011). There was a lack of food, water, and sanitation. Many of the sick died while waiting, and were buried on the spot. ${ }^{11}$ The misery of one, however, was the opportunity of another, and some grasped at the newly available business opportunities. 
Individuals sold meals at exorbitant prices and supplied shelter in makeshift guesthouses made of tarpaulins, and cellular phone companies quickly set up their transmitters. The government was obliged to begin regulating access to the area in order to prevent a humanitarian crisis (e.g., Majira 12 March 2011; observation). Samunge had been transformed from one of the remotest spots in Northern Tanzania into a place of international interest.

The medicine itself and the ministry around it was not much of a novelty. The roots of the mugariga ${ }^{12}$ tree have been widely used for various medicinal purposes, not only among the Sonjo but also in several other East African ethnic groups such as the Maasai, Barabaig, and Kurya (Malebo and Mbwambo 2011). It looks like many herbal medicines: a brownish concoction containing tiny particles. The taste is not overly bitter, resembling that of willow bark. It has never been considered a miracle medicine for any illness, though according to two of my informants of Maasai background it has been used for venereal diseases (FD-Informal discussions 30 Jan 2012, names withheld).

The distribution of the medicine does not represent a specific innovation in ritual. The central premise of the act of healing is that in order to be effective, the medicine needs to be measured out by Babu himself, using the miraculous cup (Mwakalinga 2011), which is why the treatment is popularly called 'grandpa's cup' (kikombe cha Babu) (see, e.g., Maige 2012). ${ }^{13}$ That the beneficial effects of a medicine are dependent on the person administering it is, once again, a belief also found among traditional healers (Langwick 2011). During the busiest periods, the distribution simply consisted of Babu measuring the fluid from twenty-litre buckets (madebe) into cups that were then dispensed to patients waiting in a queue. In times of less pressure, patients would gather in a circle to hear the Babu briefly explain the way in which the medicine functioned: some sicknesses required a longer period to be overcome by a single dose, and one should not drink alcohol immediately after its ingestion. In these addresses he also pointed out that it is God who heals, rather than the pastor himself or the medicine (FD-observation; Mwakalinga 2011). This was then followed by collection of a fee of Tsh 500 (about twenty UK pence) from Tanzanians, or one U.S. dollar from foreigners. ${ }^{14}$ A prayer was then spoken, whereupon the medicine was distributed:

God, all these people have come to me from far away. They have come to you because you have placed your miracle here. I beg you now, God, to take away all their illnesses. Lord, take from them this burden so that they can return with new life.... There is no sickness that can deceive God.... Again, you, God created them with holy hands with no sickness-sicknesses do not come from you but they have come from Satan, witchcraft, 
and sorcery. I renounce them with the authority you gave me over their bodies... Thank you for hearing our prayers.... I pray believing that you fulfil these requests in the name of our Lord Jesus Christ. Amen. ${ }^{15}$

However, the public interest in the healing miracles waned as quickly as it had risen. June 2011 was the watershed in the printed media and on the Internet. Babu encouraged people to leave their conventional medicines even though he did not command them to do so: 'I asked God, and he answered that after having drunk this medicine, it will replace the pills. Now, I tell you that it also depends on your faith. If it is little, you should continue with your pills'.16 An increasing number of stories began to appear about how people with AIDs had stopped taking their ARVs and died, or of people dying while waiting in the queues, and the general frenzy calmed down. Eventually, as at the time of my interviews with Babu, there were days when no one or only a few came for treatment.

It is difficult to estimate even approximately the number of persons who visited Samunge during the great 'jam'. In some media the suggested figures ran to several millions, clearly a gross exaggeration. In others the daily number of visitors was sometimes reported as 4,00o on average (e.g., Tanzanian People 2011). According to Babu, during the busiest period they once counted that they had distributed 17,000 cups of medicine. Since the highest period of congestion lasted for about one hundred days the figure is clearly massive, though it can be estimated with a degree of certainty at probably less than one million. However, these figures need to be viewed against the backdrop of geographical isolation, poor road infrastructure, and poverty, all of which created considerable obstacles for people wishing to reach Samunge.

\section{Healing and Realpolitik-The Power Struggle in the Shadow of Grandpa's Cup}

ELCT bishops supported Babu's ministry as soon as it became known in the media (e.g., Nipashe 9 March 2011), and only made positive statements on the subject to reporters. Additionally, some bishops visited him at an early stage and drank from the cup (FD), thereby strongly communicating their view of the pastor's trustworthiness and theological soundness. The Tanzanian Lutheran approach to traditional healing is traditionally very negative inasmuch as it is not a matter of pure herbalism but includes spiritual powers as well (Vähäkangas 2002). Likewise, the Lutheran church leaders' approach to Christian faith healing has been reserved in spite of strong pressure to endorse 
it from the grassroots level. The reason for the bishops' quick recognition can be generally traced to the tough competition in the Tanzanian religious market. In the ELCT, spiritual churches are generally seen as a threat due to the fact that a good number of Christians from the established denominations move to them. Babu therefore appeared to raise the possibility of fighting back, using their own weapons.

In addition to giving the ELCT some leverage against the spiritual churches, the modest fee charged by Babu, when multiplied by the incredible numbers of his visitors, became a true economic asset in the Tanzanian context, meaning that the bishops wished to exercise closer control over the pastor. As a retired pastor he was in a grey zone-subservient to the bishops as a pastor but no longer financially or organizationally dependent on them as a pensioner. Some of the funds accumulated in Samunge were continually being spent on the production of the medicine. A support bank account for Babu's ministry was opened and publicly announced by the ELCT Diocese in the Arusha Region, albeit without Babu's consent. Likewise, the diocese came to a unilateral decision to build a centre for him (Nipashe 11 March 2011; Nipashe 31 March 2011). The plan was probably to get people to donate funds to the healer through the bank account, thereby creating the leverage to control him and possibly to bargain with him. The church also announced unilaterally that a certain part of the fee would belong to the church - the financial dividends of healing had become intriguing (see Majira 30 March 2011; Babu 5; FD). Babu turned down all such initiatives, telling the bishops that God had not told him to join them (FD). He obviously had his suspicions about the integrity of church leadership even though he did not express it. Bishop Laizer had internal credibility issues in the diocese, so some additional funds as well as some transfer of Babu's celebrity would have been useful to him.

The attitude of government officials toward Babu went through stages. In the beginning, when the upcoming healer was only a local phenomenon, the local authorities attempted to block his ministry (The Citizen 2011; Nipashe 10 March 2011; FD informal discussion with Babu). The next step was to admit that it was not feasible to try to curb the rush to Samunge, and a neutral position was adopted (Nipashe 12 March 2011) until the initial scepticism turned into an interest in the possible financial opportunities. The district charged vehicles entering the area, thus producing an enormous income that was supposed to be used to improve the infrastructure (Philemon 2011). Local health officials also wanted to incorporate Babu into the governmental health care system of the Loliondo district. An important part of the plan was the financial aspect, with its administration to be transferred to governmental hands. Babu's response was the same as to the bishops: this is not what God wants (Babu 5). 
When Babu's increasing popularity attracted threats from competitors, the government felt it was wise to guard his safety. Although this was not publicly announced, news about the security measures began to circulate as a rumour, appearing in the media only later. When armed bodyguards were seen around the pastor on his visit to Babati, the journalists could not miss it (Shout Africa 2011; Majira 21 March 2011). This made Babu into a VIP in the eyes of many, even though the government's aim had been simply to avoid the unrest that an assassination would have caused. Wild rumours circulated about attempts against the pastor's life and his miraculous protection by God, but when asked he did not confirm any of these as true. However, he told me that one patient came with a snake in his pocket to kill him. In what Babu probably saw as divine intervention, the would-be assassin himself fell dead (Babu 3; Mwakalinga 2011). He certainly considered threats made against his life by his competitors to be real (Babu 2; Babu 3).

Tight security measures were put into place. Visitors only wishing to partake of the cup were allowed to go directly to the healer, whereas there was a strict procedure for those who wished to have conversations with him. Following the procedure, I had to secure a letter from the regional headquarters in Arusha, take it to the district officer in Loliondo, and could only then proceed to Samunge. ${ }^{17}$ There I was first received by a person describing himself as an assistant to Babu. He was present at every session when meeting with Babu. Judging from the way he was treated by the other assistants, it was easy to conclude that he was one of the much-rumoured, government-placed bodyguards.

Tanzanian political figures on the national level soon recognized the possibilities. One after another, members of Parliament rented buses to take ailing people from their constituencies to Babu. This was, of course, widely publicized in newspapers with full details of costs and numbers of people taken for healing. ${ }^{18}$ Cabinet ministers arrived to assess the situation and donated funds for the healing ministry (Nipashe 28 March 2011). Even if the state machinery was not directly involved, wide political participation in Babu's faith-healing business naturally made it look as if it were authorized by the government, something well suited to the clientelistic political culture of Tanzania (see, e.g., Chabal and Daloz 1999). Very few politicians, even from the opposition, dismissed Babu; one of the few was Christopher Mtikila, a pastor-cumopposition-politician who dismissed the whole phenomenon as a ruling party (ССM) trick (Majira 21 March 2011).

Thus it was not only the pensioned pastor's humble sincerity and customer satisfaction but also the ecclesial and governmental authorities' desire to cooperate with and, if possible, co-opt Babu's ministry that gave it the needed credibility. However, as soon as bad news from would-be healed patients began 
to gain the upper hand, it became clear that the people's excessive expectations were not being met (e.g., Nipashe 15 April 2011). H IV positive patients who had given up their ARVs began to die en masse, causing the rest to return to their conventional treatments. ${ }^{19}$ Negative publicity increased scepticism and intensified the questioning of Babu's integrity both directly and indirectly. Reference was made to facts or fabrications that posed him in a negative light, such as the death of his son to malaria; the deaths of dozens of sick people queuing for the cup; allegations of the increased price of the medicine; and alleged government financing for his newly built home with its solar-powered energy, television (see, e.g., Wesangula 2011; FD referring to Uwazi Agosti 2011 and Desemba 2011). There were also cases reported of negative effects from the cup (Nipashe 16 May 2011). In spite of Babu's attempts to refute misinformation on the new price of the medication or on putative government funding, the tone of media coverage had already turned from marvel to scepticism. As a result, the quickly increasing upward spiral of media visibility and numbers of patients became an accelerated downward spiral, leading to the swift waning of the authorities' interest in the pastor: he was no longer useful. Media coverage ended abruptly and almost completely in June 2011. Afterward the perspective taken was typically that of assessing the damage caused by the frenzy with which HIV positive patients had discarded their ARVs (Maige 2012).

However, Babu continued to believe in a renewed rush of people - this time mostly from abroad — as he had been informed in dreams. At the time of my interviews he was working with his team of assistants to clear an area just outside the village of Samunge in order to build a reception centre for the future multitudes. The team had a sense of urgency; they wanted to be well prepared for the next inundation of patients (FD-observation 2 February 2012; Nkwame 2012). However, the next rush to the village was a gold rush — gold nuggets had been found in the creek running through the village, the same creek where I had sometimes done my morning wash, marvelling at the glint at the bottom of the creek. The search for health had turned into a search for wealth (Juma 2014).

\section{What Draws Multitudes to the Wilderness?}

What did you go out into the wilderness to see? A reed swayed by the wind? If not, what did you go out to see? A man dressed in fine clothes? No, those who wear fine clothes are in kings' palaces. Then, what did you go out to see? A prophet? (Mt. 11: 7-9, NIV) 
On the surface, the attraction of Babu seems to depend on several dimensions. The first likely explanation is a John-the-Baptist effect. According to the Gospel writers, John the Baptist was an ascetic preacher in the wilderness. His preaching did not seem to benefit him at all financially and, by following his calling, he attracted the unwelcome attention of King Herod who had him decapitated. Simon Kimbangu, a Congolese prophet with a half-year's ministry in 1921 before he was taken into captivity by Belgian colonial authorities, was a similar figure. His ministry did not bring him wealth but rather persecution (Martin 1976). As with Babu, healing was also central in Kimbangu's ministry, and it attracted great hordes of people to his remote village. Babu seemed to follow the same path as a very low-key person in regard to his lifestyle and background. As with John the Baptist and Kimbangu, money was obviously not the motivation for establishing his ministry, though compared with the two others Babu's ministry did not cause him to become a target of persecution. As modest men, all three compare favourably to the charlatans, miracle makers, and healers who preach about seed money and collect funds from patients in all the major religions in Tanzania.

Babu's fee of Tsh 500 for Tanzanian visitors is lower than the price of a bottle of soda, and it is probably clear to patients that it is needed to keep the ministry running. Babu states that the amount was set by God. ${ }^{20}$ The very modest fee removes the obligation to contribute to a collection or provide a gift for the healer. In the traditional setting, one never comes to a healer empty handed; the transactions usually include either offerings to the spirits or payment to the healer, often both. In the setting of Tanzanian spiritual churches the payment takes the form of a collection, and there is often a strong social and spiritual pressure to give as much as one can and sometimes more. Seen in this light, the token payment required is more a release from the obligation to pay rather than a proper business transaction (for comparison, see Lindhardt 2012b). The giving of additional offerings by the patients is allowed but not encouraged ( $\mathrm{FD}$, discussion with $\mathrm{Babu}$ ). It is thus possible that the patients considered the nominal fee to be a sign of honesty and transparency compared with an absence of a fee that could be interpreted as false modesty aiming at extracting offerings, or with charging a high fee thereby exposing egoistic motives on the part of healers.

The lack of an organizational framework as well as ritual simplicity led Babu's ministry to a very high degree of openness that can be counted as another dimension of his ministry contributing to his popularity. There are no exclusively Christian features in a ritual that consists of a simple administration of a traditional medicine that becomes operational by virtue of its being 
administered by the one chosen by God and of simple prayers directed to God. Much of the ritual refers directly to the traditional religions without being a distinctive tradition of a specific Tanzanian ethnic group. At the same time, Babu's background and his interpretation of the efficacy of the medicine based on the Word of God gave Christian recipients keys to interpreting the phenomenon within their faith. Being so religiously open, the healing ministry does not present obvious obstacles to Muslims. ${ }^{21}$ Tanzanian Muslims' approach to healing is quite open and pragmatic in the sense that healing is sought after wherever it is available. This means that a person from any religious background could relate to Babu's healing, thus opening it to the entire market of the Tanzanian population. Regarding Tanzanian traditional worldviews, the efficacy of words makes sense because in healing, incantations or other verbal elements make up a part of the treatment alongside the material medicine. ${ }^{22}$

The third dimension of Babu's credibility was his track record. Very few would have any doubts about his calling given his status as a retired pastor who had worked for a long time as a missionary with extremely modest benefits. Furthermore, Babu's aura of credibility was enhanced by having served as a pastor of the ELCT, the second-largest established church in Tanzania. Its strict hierarchy and very few possibilities for lower-ranking pastors to tap church resources for their personal benefit were well known. Newspaper articles dealing with Babu the person generally depict him as a humble man living a very simple life. It almost goes without saying that this provides a sharp contrast to the luxurious lifestyles of many healers who, from an outsider's perspective, seem to devour the resources of their less-fortunate followers.

The fourth dimension of credibility has to do with the wide recognition Babu gained from the Lutheran church authorities. Bishop Laizer in particular presented himself as the protector of the newly popular pastor in the face of government officials (e.g., Nipashe 11 March 2011, 4). What made the ELCT bishops' support more credible is that the ELCT is not generally known as a church that holds spiritual healing in very high regard, even though such a phenomenon does exist there (see, e.g., Lindhardt 2012a). Thus, in comparison to the churches that regularly advertise healing, this case appeared special and therefore more genuine. On the other hand, there was a degree of religious opposition to Babu, particularly among competitors. It was not limited to Christians - there was also Muslim criticism of his ministry (Majira 28 March 2011) and some media joined such campaigns. However, during the heyday of the pilgrimage such attacks probably served as advertisements for the pastor rather than the opposite - if the big-name, wealthy preachers in the capital are preoccupied with him, he must certainly be something special! 
There were many people in the media who proclaimed their healing to be the result of Babu's medicine. Some were respected politicians like the former minister and presidential candidate Augustine Mrema, who went so far as to announce in Parliament that he had been healed of diabetes (Mhegera 2011; Nipashe 30 April 2011; FD). There were also rumours about national and foreign dignitaries who may have come to drink from the cup (see, e.g., Gettleman 2011; Tanzanian People 2011; Tanzanian Affairs 1 May 2011), though Babu himself was reluctant to claim prominent dignitaries as his patients $(\mathrm{FD}, 17$-informal discussion with Babu).

Yet another dimension behind Babu's success is the devastating effects of HIV/AIDS on Tanzania and the omnipresent fear of the disease. The 199os and the beginning of the millennium saw a rapid expansion of the pandemic, especially among the urban working-age population, turning many providers for the family into burdens. The ARVs available from the mid-20oos have given a glimpse of hope and reduced AIDS-related deaths considerably. Furthermore, the number of HIV-infected people also decreased (UNAIDS 2012). In spite of the improving situation, Babu's medicine was perceived as a divine intervention to help the afflicted nation. The chairperson of Tanzania's HIV+ people travelled to Babu and reported afterward that he had improved after the medication. However, he advised that no one should give up the ARvs until they tested negative for HIV three times (Nipashe Jamii 5 April 2011). The medicine was considered a second chance for H IV-positive people but regarded as a oneoff cure that would not function on a second occasion, and therefore patients should avoid loose sexual relations after drinking from the cup (Majira 15 March 2011). Word of mouth was thus a strong element in Babu's appeal; even a year after the 'jam' it was still easy to find many people who claimed healing or improved health as the result of Babu's ministry: Christians and traditionalists, old and young, university educated and noneducated, and from various ethnic backgrounds (FD ad passim). There was probably no stronger incentive for a sick person to rush to Samunge than hearing a friend say that they had been cured by Babu's cup.

\section{Discourse in between the Paradigms within Plural Medicine}

This section views the discourse surrounding Babu's ministry from the points of view of the three most relevant healing options to this study, namely Christian faith healing, African traditional healing, and biomedicine. References from Muslim healing cannot be found in the discourse even in the Internet chat 
comments of Muslim participants. However, it is useful to note that most of the reporting on his ministry offers very little material for analysis since the majority of the news reports focused on the inaccessibility of Samunge and the length of its car queues. The most interesting media material comes from comments in favour of or against Babu.

The debate over Babu generally revolved around the question of whether he represented Satan (i.e., African religious traditions in much of Christian parlance) or Christianity, and whether he was a charlatan or if his healing actually functioned in the medical sense. The first dimension of the discourse had strong Christian overtones, and the basic issue was thus whether Babu's ministry should be counted as properly Christian faith healing or whether it was a case of African traditional healing camouflaged in Christian forms. The second dimension on medical efficacy was a biomedical approach to his treatment. This debate actually reproduced the colonial approach to traditional healing that viewed the premodern forms of healing as either deceit or witchcraft (see Langwick 2011).

When leaders of the ELCT drank from Babu's cup, it conveyed a strong message that his status as a Christian faith healer was accepted because, in continuity with colonial and missionary ideology, the ELCT does not accept traditional healing except in the case of herbal medicines (M. Vähäkangas 2002, see Langwick 2011). The fact that the treatment was traditional did not in itself create a problem, and were it merely a matter of an herbal medicine the issue could have been left to the assessment of representatives of biomedicine, thereby positioning the question as an encounter between African traditional healing and biomedicine. However, the fact that Babu strongly emphasised the spiritual nature of his healing practice forced the church authorities to react in a more theological manner. Therefore references were made to prayer and faith, and assurances given that this healing had nothing to do with witchcraft. At the same time, Bishop Thomas Laizer of the diocese in the Arusha region emphasized Babu's theological pedigree and his dependency on him as the bishop because he had ordained him. Laizer also described how he had been healed from his health problems (Nipashe 9 March 2011). One of the central tasks of a Lutheran bishop is to supervise the doctrinal orthodoxy in his diocese, and the ELCT message to the public was strong: this healer is a true Christian - and by connotation, not a traditionalist healer. The Moravian Church is both theologically and practically close to the ELCT, and its archbishop, Alinikisa Cheyo, also expressed his support for Babu (Majira 21 March 2011).

Only a few leaders of the spiritual churches supported Babu, such as Anthony Lusekelo and Josephat Gwajima (Mwakalinga 2011), who agreed 
that his powers came from God. On the other hand, some of the healers in the spiritual churches, like the famous Zakaria Kakobe, attacked Babu in poisonous terms and attempted to ruin his reputation (Mwakalinga 2011; see Mosoba 2011). Kakobe was reported exhorting his followers to 'Trample on Babu wa Loliondo, destroy Babu wa Loliondo, crush the works of Babu', asserting that the retired pastor made use of the powers of darkness. ${ }^{23}$ It was obvious that, in Kakobe's eyes, this new healer represented satanic powers in the same way as African traditional healers. The identification between the traditional African spirit world and Satan is based partly on missionary teaching and its reception among today's African Christians (Meyer 1992) and partly on the linguistic resonances between Kiswahili mashetani (evil or ambivalent spirits) and the Biblical concept of Satan (see Langwick 2011). The discourse of whether a competing preacher or healer represents God or Satan is not rare, and often includes attempts to demonstrate the competitor's connections to traditional healing and divination. In Babu's case this was easy due to the traditional nature of the material medium of healing. The Catholic Archbishop Polycarp Pengo also warned against Babu, though in a considerably more civilized manner, calling on people to be careful with the healer (African Outlook Online 2011).

Becoming a celebrity also brought Babu onto the East African political agenda. When noting the Kenyan multitudes heading toward the Tanzanian hinterlands for healing, the Kenyan minister for health, Beth Mugo, warned against what she considered a hoax. According to her, Babu should have been stopped or imprisoned. Her objection was not to praying for the sick but rather to replacing biomedicine with faith healing (ETM 28 March 2011; Philemon 2011; Nipashe jamii 12 April 2011). Minister Mugo's approach was thus largely medical; her argumentation built on biomedical categories while having certain moralistic undertones. Although her comments could possibly be interpreted as merely an attack on Babu's integrity and not a confrontation between two competing health paradigms, she actually appeared to be labelling all spiritual healing a hoax, thereby instigating a scientific frontal assault against the entire category. ${ }^{24}$ Furthermore, in addition to possibly genuine concerns, the fact that such great crowds sought healing outside the official health care system could be seen as proof of failure of the governmental health sector in Kenya. There is also a general, albeit seldom openly expressed, Kenyan opinion of Tanzanians as more backward than they are. Thus a Tanzanian solution to Kenyan problems definitely went against the grain. In response, the Tanzanian minister for health, Hadji Hussein Mponda, a man of Muslim background, promptly stood up in support of Babu (Nipashe 28 March 2011), bringing to the issue an element of nationalistic competitiveness. It should also be recognised that at that 
moment Babu was probably the most popular figure in Tanzania, so public support for him on the part of politicians can be seen as a tactical political move, buying plenty of goodwill among the voters. This does not, however, discount the fact that the Tanzanian minister for health spoke out to defend a form of healing that had no biomedical support at that point.

Babu's medicine eventually received official recognition as a result of laboratory tests conducted by Muhimbili medical centre in Dar es Salaam, Tanzania's leading university hospital. Testing traditional medicines is among the regular tasks of Muhimbili, so this was not extraordinary (see Langwick 2011). Babu himself was sceptical about the process: 'When they sent people to collect the medicine to test it, I told them that they will see things but will not see the Word of God. So, they will labour with the tree but they won't see the Word of God in it'. ${ }^{25}$ On the one hand, this attitude tried to secure the sacred nature of his healing, but on the other it probably also reflected widespread Tanzanian scepticism about modernity, the results of which are greeted with ambivalence at the grassroots level (see Becker 2009). However, the findings of the tests were astonishing. The report revealed that the medicine contained several substances that could have curative effects on a long list of illnesses. The results stated that the research conducted or previous research referred to supported 'the ethnomedicinal claim' made by Babu of his treatment- that it could cure epilepsy, diabetes, high blood pressure, heart problems, liver disorders, cancer, herpes simplex virus, and also management of H IV/AIDs (Malebo and Mbwambo 2011). The wording does not, however, claim that the healing effects are fully proven, only that the medicine contains substances that support the claims of curing. This report introduced a strong scientific voice to the public debate in support of Babu.

As noted above, the fact that Muhimbili decided to test the medicine was not surprising. Considering the popularity of the medicine, there was considerable pressure to ensure that it was not harmful, even if the healer himself regarded the testing as useless. However, the fact that the report gave a carefully worded support to the claims of efficacy was surprising. One may only wonder whether the media frenzy around Babu affected the judgment of the researchers.

The media also reported on medical practitioners who claimed that, for example, an HIV positive person could have become HIV negative after Babu's cup, according to their own series of tests (Smart African Travel 2011). Reports of medical doctors from leading Tanzanian hospitals standing in the queue to get the cup also helped create an image of Babu's medicine as biomedically effective (Majira 14 March 2011), while quasi-scientific investigations further added to its credibility, claiming high success figures (Herbal medcines [sic] 
11 August 2011; Nipashe 4 May 2011; see also Radio Islam Malawi 2011). Thus the treatment began to develop something of a scientific aura. The fact that there were medical practitioners telling the media that they continued screening HIV in their patients even after they had drunk the cup did not diminish the popularity of the Loliondo journeys (Namu 2011, 3-4). The few critical reports or even voices from well-known figures pointing out that their relatives had not been cured or had died were drowned in the general euphoria (see, e.g., Risasi 2011; Matinyi 2011; Majira 13 March 2011). Meanwhile, even though some voices maintained the rift between the more materialistically oriented biomedical paradigm and the two more spiritually oriented forms of healing, the public obviously wanted to hear those who proclaimed Babu's scientific acceptability.

\section{Between Cultural Categories-A Surprising and Temporary Harmony}

A retired pastor of an establishment church becoming involved in faith healing points to major cultural tensions. It is clear that African emic cultural analysis must take into account the encounter between local and European ways (see, e.g., Comaroff and Comaroff 1991). It is also largely admitted that this cultural tension is problematic, not least in African ecclesiastic communities (see, e.g., Healey and Sybertz 1996). However, another cultural tension that is clearly visible in Tanzanian popular debate, that between Christian and (post) modern dimensions of worldview, is often ignored in discussions of African cultural encounters. This is surprising considering that it has been one of the problematic issues within the Western cultural sphere, often taking the form of debates about faith and science or the role of Christianity in a secular state.

According to Hasu (1999), since the 1920s or earlier the Chagga of northern Tanzania have distinguished between the categories of indigenous (kiafrika, African/kienyeji, local) and kizungu (European) or kikristo (Christian). With the indigenization of Christianity among the predominantly Christian Chagga, the indigenous category began to increasingly overlap with the kikristo category. However, later Western influences eventually came to play the role of the other in the sense of kisasa (modern) (Hasu 1999). Kienyeji is related to African traditions that may stem from precolonial times, but can likewise be contemporary inventions claiming African ancestry or African reactions to the encounter with the two other cultural categories. Kikristo ${ }^{26}$ refers predominantly to Western missionary Christianity and therefore has a certain foreign aura. Yet at the same time, the life and faith of the historic churches have had a century to adapt themselves to the Tanzanian context, as Hasu points out 
(1999). Often the process has been mutual—missionary Christianity has influenced the kienyeji traditions while the kienyeji traditions in turn have modelled the ecclesiastic traditions. The resulting kikristo category thus often strongly differs from the traditions of historic churches in the global north that have developed in quite different directions during the last century. ${ }^{27}$ Kisasa is a messy category of science, business, and postmodern influences, all of them foreign and more or less Western. Thus 'modernity' is a translation that covers only a part of its meaning. ${ }^{28}$

These cultural categories are neither material nor easily distinguishable, and yet they comprise an emic interpretative pattern of the tensions within the culture of Tanzanian Christians, in the sense of Clifford Geertz's definition of culture as 'a set of control mechanisms - plans, recipes, rules, instructions (what computer engineers call "programs")—for the governing of behavior' $(1973,44)$. The cultural categories can best be understood as competing, albeit often partly overlapping, sets of values, ethics, aesthetics, epistemology, and norms. A specific behaviour, institution, or tradition can be perceived as incarnating one or more of the cultural categories. These three categories should thus not be seen in an essentialist manner or as mutually exclusive. The observer's position and the question at hand defines whether, for example, a certain dimension of Charismatic Christianity should be classified as kisasa or kikristo, or even kienyeji. In many cases different phenomena combine elements of two or three of the categories. Neither should one consider these categories constant in the sense that a phenomenon or value is unable to move from one category to another in the course of time. The so-called spiritual churches can be classified in the category of kisasa by virtue of their representation of pluralism, a variation from traditional missionary Christianity (thus A. Vähäkangas 2011), yet in today's Tanzania they increasingly represent the Christian voice in the public sphere through their strong media presence. At the same time, their position in society has become less marginal. Here the border between kikristo and kisasa seems to be fluctuating and the categories overlapping.

There tends to be a certain ambiguity vis-à-vis each of the categories, all of them containing useful, ambiguous, and harmful dimensions in the view of Tanzanians. Sometimes even the dimensions regarded as useful in different categories are not compatible. As a result, tensions between them are inevitable. These three cultural categories are visible even in everyday language, and there is widespread understanding among the people about the field of tension between them in which they must operate and, hopefully, cope. The most usual tensions in popular deliberations are between kienyeji and kisasa (ranging from types of chickens to modes of governing and behaviour) as well as kienyeji and kikristo (often referring to ways of life). The tension between kikristo 
and kisasa, Christianity and (late) modernity, takes place predominantly in the sphere of morals and lifestyles rather than conflicting truth claims of science or pluralist worldviews vis-à-vis Christianity common in the global north (see Hasu 1999).

Healing seems to be one of the main areas in which these three cultural spheres collide but also mix and produce new variations of patterns. ${ }^{29}$ During the early missionary period, kikristo as missionary Christianity and kisasa as Western scientific worldview joined together in an effort to combat pagan superstition while at the same time keeping medicine and religion discrete: mission stations often had both a church and a hospital, separate from each other. The sick could be prayed for and the medical and spiritual personnel could refer patients to each other, but these two functions were not usually mixed (see, e.g., Åhman 2013). However, the spiritual dimension of healing was often regarded with unease, probably because traditional religiosity very much revolved, and still revolves, around healing (see Stroeken 2010). Thus missionary healing services became a field in which kikristo and kisasa had an uneasy alliance (see Ranger 1992; Wilkens 2009). With the faith healing of spiritual churches and groups, kikristo has begun to gain more relevance in the kienyeji sphere by more effectively answering the expectations of traditional African worldviews (see Becker and Geissler 2009). In terms of healing and deliverance in particular, the spiritual churches are adopting Africa's traditional agendas and thereby bridging the gap between kikristo and kienyeji.

There have also been attempts to reconcile kienyeji and kisasa, traditional medicine and biomedicine, since it has become apparent that it is not plausible to expect that biomedical approaches can respond to all African medical needs. This has been the case partly because of the limitations of African states' financial resources, and partly because the biomedical paradigm does not respond to spiritual and communal needs, offering only curing rather than healing. The wHo, for example, has recommended cooperation between bioand traditional medicines (Feierman 1985; Devisch 1993). The Tanzanian government has followed suit by establishing contact between biomedical and traditional practitioners, attempting to register the latter and regulate their medicines (Langwick 2011). Likewise, traditional medical practitioners attempt to combine the kienyeji and kisasa categories by adapting some dimensions of their activities to modern medicine (see Langwick 2011). Thus it is quite common to see traditional healers dressing themselves in white robes like hospital staff, or even building traditional clinics. Sometimes there are attempts to fuse traditional and modern technology, as in the case of a healer in Northern Malawi who advertises 'spilitial x-ray', or spiritual x-ray. What made Babu's ministry different from other faith healers is that his healing ministry became 


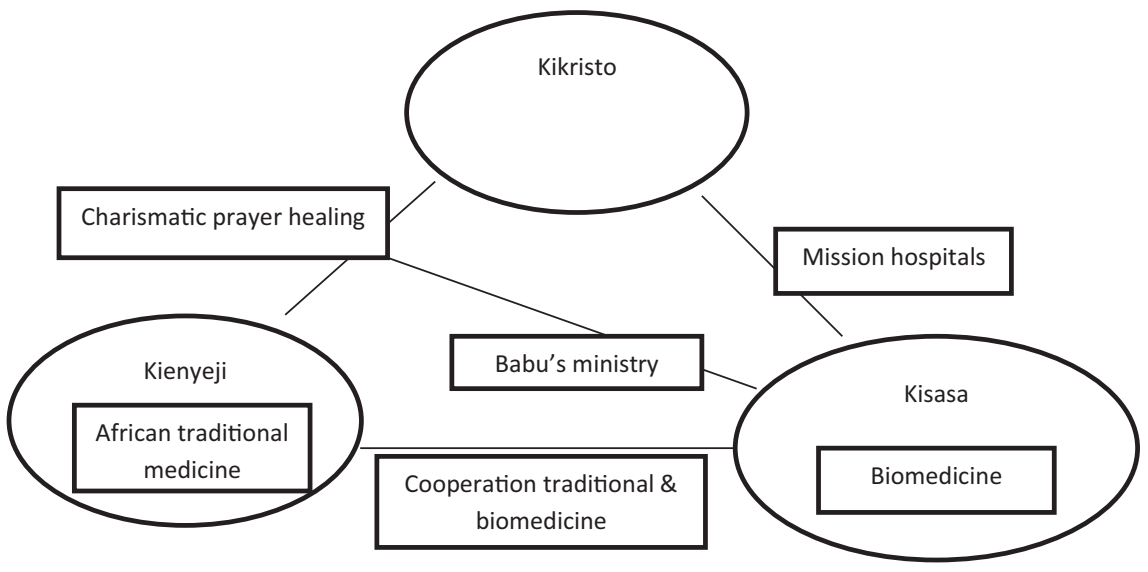

FIGURE 1 The location of the different medical paradigms among the three cultural categories as explained above.

an event where the tensions of the cultural spheres were temporarily resolved in a manner that Babu could not have been planned because it went against his theological conviction that the medicinal treatment he offered did not function on the basis of the herbal ingredient (see Figure 1).

African life in the field of tension between the cultural spheres is not easy. Members of the churches are generally not supposed to visit traditional healers, yet in Western missionary Christianity the realm of the spirit world is often ignored as the source of illness. According to Auli Vähäkangas, one of the successful coping strategies in this cross fire of expectations is to find solutions where two or all of the categories merge together (A. Vähäkangas 2009). Charismatic prayer healing resolves the tension between kienyeji and kikristo, at least in part by an eclectic adoption of the agenda of traditional worldviews. However, at the same time the truce between Christianity and the Western scientific worldview that the historic churches have been able to construct is breaking down. Resolving one tension thus reintroduces another. Importing Christianity into the African world in which the spiritual dimension permeates all of the material inevitably expels Christianity from the predominantly materialistic scientific world of the West.

In Babu's ministry one can identify a bridge that creates a unity between all three cultural dimensions. Babu's ministry effectively includes the traditional via the medium of a herbal medicine familiar to many parts of Eastern Africa. At the same time, by claiming that the efficacy of the healing is based on the power of God through the Word and prayer, he effectively connects it with the Christian cultural sphere. This connection places it in the same kikristo-kinyeji 
continuum as Charismatic faith healing. What was new in Babu's ministry was the emerging cultural bridge between the Christian-traditional healing complex that already existed and modernity or the scientific worldview, though it is a link that seems to have emerged against Babu's will. Muhimbili scientists wanted to endorse his medicine in biomedical terms even though he strongly emphasised that the chemical composition of the concoction plays no role. It also seems that he did not expect the sudden interest of the Tanzanian powers that be.

Babu's medicine could be simultaneously perceived by the patients as a revealed and therefore spiritual treatment, and an effective, scientifically verified herbal medicine. This was the dimension that allowed a form of Christian healing to have one foot in the African spirit world and the other in the Western scientific world. One should note, however, that both worlds were seen in a pragmatic light: the African spirit world was interpreted in a Christian manner and the Muhimbili report and other views on the medicinal effects of mugarika were taken at face value, with more being read into them than standard scientific procedures would probably have endorsed. The result was a feeling that a healing process now existed in which all three spheres of life were in harmony. This resolution of tensions proved to be based on a shaky ground when the deaths of patients who discontinued their ARvs forced the public to admit that Grandpa's cup (kikombe cha Babu) was not, after all, a potent miracle medicine from the scientific point of view.

One could cynically conclude that Babu became so popular that many wanted to profit from his reflected popularity and therefore related positively to his ministry. It is, however, impossible to avoid the conclusion that there is a strongly felt need for events, ideas, and persons that are able to reconcile the three cultural spheres and thereby overcome the tensions between the varying expectations people in his milieu have of life. Without any intentional planning on his part, due to his background and the way in which his ministry was received, Babu's healing temporarily created a space in which the cultural collision could be healed-until the scientific foundation of the solution collapsed as a result of obvious cases of nonhealing.

\section{Conclusion}

Rev. Ambilikile Mwasapila or Babu wa Loliondo caused a great although momentary stir in the whole of Tanzanian society. The fact that he drew such multitudes to his remote village in search of healing proves that he was able to touch a sore spot in the lives of many Tanzanians and people of neighbouring 
countries. The compartmentalized Western practice of separating health care and the spiritual dimension of life does not seem to respond to the needs of these people. Additionally, in spite of widespread condemnation of the religious dimensions of African traditions by Christian Tanzanians in particular, the urge to respond to the needs arising in the very same traditional cosmologies is still there. Biomedicine cannot respond to it because of its single concentration on the visible world. Churches once established by Western missions often lack the embodiment of the spiritual and thereby also represent the Western dichotomy between the body and the soul. Among a number of other African Christian healers, Babu was able to bridge the gap between the bodily and the spiritual. In addition, the reception of his ministry hinted for a while of the possibility of healing the built-in cultural tension between the traditional, the Christian, and the modern cultural spheres. Furthermore, the ritually open and minimalistic ministry also facilitated the opportunity for patients from any religious background to connect the healing to their worldviews. Nonetheless, when many of the supposedly healed proved to not have been cured from their diseases but rather died, the ministry proved unsustainable and its popularity swiftly waned.

\section{References}

\section{Interviews and Audio Recordings}

Babu 1-9: interviews with Rev. Ambilikile Mwasapila 1 February 2012-4 February 2012. Babu kikombe, audio-recorded participant observation.

Mama Upendo (name changed) 4 February 2012.

\section{Literature}

African Outlook Online. 28 March 2011. 'Tanzanian "miracle" pastor Mwasapile calls for break'. <http://www.africanoutlookonline.com/index.php?option=com_con tent\&view=article\&id=1405:tanzanian-miracle-pastor-mwasapile-calls-for-abreak\&catid=102:african-news\&Itemid=28> Accessed 6 October 2011.

Åhman, Bertil. 2013. 'Daniel Ndoundou—gåvornas man. En väckelseledare inom den Evangeliska Kyrkan i Kongo'. Unsubmitted manuscript for PhD dissertation, Uppsala University faculty of theology.

Allen, Tim. 1991. 'Understanding Alice: Uganda's Holy Spirit Movement in Context'. Africa 61.3, 370-399.

Becker, Felicitas. 2009. 'Competing Explanations and Treatment Choices: Muslims, Aids and ARVs in Tanzania'. In Felicitas Becker and P. Wenzel Geissler (eds.), Aids and Religious Practice in Africa. Leiden: Brill, 155-187. 
Becker, Felicitas, and P. Wenzel Geissler. 2009. 'Introduction, Searching for Pathways in a Landscape of Death: Religion and Aids in Africa'. In Felicitas Becker and P. Wenzel Geissler (eds.), Aids and Religious Practice in Africa. Leiden: Brill, 1-25.

Beckmann, Nadine. 2012. 'Medicines of Hope? The Tough Decision for Anti-retroviral Use for HIV in Zanzibar, Tanzania'.Journal of Eastern African Studies 6.4, 690-708.

Behrend, Heike. 1999. Alice Lakwena \& the Holy Spirits: War in Northern Uganda 198697. Oxford: James Currey.

Chabal, Patrick, and Jean-Pascal Daloz. 1999. Africa Works: Disorder as Political Instrument. London: James Currey/Bloomington, IN: Indiana University Press.

Comaroff, Jean, and John Comaroff. 1991. Of Revelation and Revolution: Christianity, Colonialism, and Consciousness in South Africa. Vol. 1. Chicago, IL: University of Chicago Press.

Daily News (Tanzania).

Devisch, René. 1993. Weaving the Threads of Life: The Khita Gyn-Eco-Logical Healing Cult Among the Yaka. Chicago, IL: University of Chicago Press.

Dilger, Hansjörg. 2009. 'Healing the Wounds of Modernity: Salvation, Community and Care in a Neo-Pentecostal Church in Dar es Salaam, Tanzania'. In Felicitas Becker and P. Wenzel Geissler (eds.), Aids and Religious Practice in Africa. Leiden: Brill, 255-282.

ETM, East Africa's Independent Media Review, 28 March 2011. 'Loliondo: What was the Story?' <http://www.eastafricapress.net/index.php?option=com_content\&view= article $\&$ id $=569 \% 3$ Aloliondo-what-was-the-story\&catid $=69 \% 3$ Aweekly-mediareview\&Itemid=166\&lang=en $>$ Accessed 6 October 2011.

Feierman, Steven. 1985. 'Struggles for Control: The Social Roots of Health and Healing in Modern Africa'. African Studies Review 28.2/3, 73-147.

. 2000. 'Explanation and Uncertainty in the Medical World of Ghaambo'. Bulletin of the History of Medicine 74.2, 317-344.

Geertz, Clifford. 1973. The Interpretation of Cultures. New York: Basic Books.

Gettleman, Jeffrey. 2011. 'Crowds Come Over Roads and by Helicopters for Tanzanian's Cure-All Potion'. New York Times 28 March 2011. <www.nytimes.com/2011/03/29/ world/Africa/29potion.html?_r=0 > Accessed 3 May 2013.

Gray, Robert F. 1963. The Sonjo of Tanganyika: An Anthropological Study on an Irrigationbased Society. Oxford: Oxford University Press.

Green, Maia. 2003. Priests, Witches and Power: Popular Christianity after Mission in Southern Tanzania. Cambridge: Cambridge University Press.

The Guardian (Tanzania).

Hasu, Päivi. 1999. Desire and Death: History through Ritual Practice in Kilimanjaro. Transactions of the Finnish Anthropological Society 42. Helsinki: FAs.

Healey, Joseph, and Donald Sybertz. 1996. Towards African Narrative Theology. Nairobi: Paulines Publications Africa. 
Herbal Medcines [sic]. 11 August 2011. '78pc of Patients Claim Mwasapile's Concoction Cures.' < http://herbalmedcines.com/herbal-medcines/78pc-of-patients-claimmwasapiles-concoction-cures $>$ Accessed 6 October 2011.

Hinfelaar, Hugo. 1991. 'Women's Revolt: The Lumpa Church of Lenshina Mulenga in the 1950s'. Journal of Religion in Africa 21.2, 99-129.

Huizer, Gerrit. 1985. 'Health and Healing in Global Perspective: Should the Rich Learn from the Poor?' Mission Studies 4.2, 75-99.

IQ4News. 30 March 2011. 'Why Babu Ambilikile Mwasapile [sic] of Loliondo wonder should be a candidate for Nobel Prize in Medicine'. <http://m.iq4news.com/ archive/gwiji/why-babu-ambilikile-mwasapile-loliondo-wonder-should-be-candi date-nobel-prize-medicine> Accessed 6 October 2011.

Iversen, Hans Raun. 1981. Tanzania tur/retur: Syv tekster om socialism og mission. S.l.: FK-Tryk.

Iversen, Hans Raun. 1984. 'Case Studies in the Christian Ministry in Ujamaa: Sonjothe Shortcoming of Approaches to Mission and Boay-the Emergent African Church'. Unpublished paper presented at the Conference Religion, Development and African Identity, Uppsala, 16 to 21 August 1984, Scandinavian Institute of African Studies, Nordic Institute for Missiology and Ecumenical Research.

Jansen, Gerard. 2001. 'The Labyrinth of Medical Pluralism in Africa: A Missiological Appraisal, AD 2000'. Missionalia 29.1, 69-91.

Janzen, John M. 2002. The Social Fabric of Health: An Introduction to Medical Anthropology. New York: McGraw Hill.

Juma, Mussa. 2014. 'Baada ya kikombe cha Babu, dhahabu yaibuka Samunge', Mwananchi 21 May 2014. http://www.mwananchi.co.tz/habari/Kitaifa/Baada-yaKikombe-cha-Babu--dhahabu-yaibuka-Samunge/-/1597296/2321910/-/xhl8ij/-/ index.html Accessed 1 April 2015.

Langwick, Stacey A. 2011. Bodies, Politics, and African Healing: The Matter of Maladies in Tanzania. Bloomington: Indiana University Press.

Lindhardt, Martin. 2010. "If You are Saved, You Cannot Forget Your Parents": Agency, Power and Social Repositioning in Tanzanian Born-again Christianity'. Journal of Religion in Africa 40.3, 240-272.

- 2012a. 'Who Bewitched the Pastor and Why Did He Survive the Witchcraft Attack? Micro-politics and the Creativity of Indeterminacy in Tanzanian Discourses on Witchcraft'. Canadian Journal of African Studies 46.2, 215-232.

_ 2012b. 'Miracle Makers and Money Takers: Healers, Prosperity Preachers and Fraud in Contemporary Tanzania'. Unpublished manuscript.

Maige, Salum. 2012. 'Waliopata kikombe cha Babu wazidi kupoteza maisha' Mwananchi, 10 December. <http://www.mwananchi.co.tz/habari/Kitaifa/-/1597296/1640594//11prif6/-/index.html> Accessed 10 May 2013.

Majira February-June 2011. 
Malebo, Hamisi M., and Zakaria H. Mbwambo. 2011. 'Technical Report on Miracle Cure Prescribed by Rev. Ambilikile Mwasupile in Samunge Village, Loliondo, Arusha'. Department of Traditional Medicine Research, National Institute for Medical Research \& Institute of Traditional Medicine, Muhimbili University of Health and Allied Sciences.

Martin, Marie-Louise. 1976. Kimbangu: An African Prophet and His Church. Grand Rapids, MI: Eerdmans.

Matinyi, Mobhare. 2011. 'With an eagle's eye: Are the healing wonders of Loliondo real?' The Citizen, 11 March. <http://thecitizen.co.tz/editorial-analysis/47-columnists/ 8970-with-an-eagles-eye-are-the-healing-wonders-of-loliondo-real.html > Accessed 6 October 2011.

Meyer, Birgit. 1992. "If You are a Devil, You are a Witch, and if You are a Witch, You are a Devil": The Integration of "Pagan" Ideas into the Conceptual Universe of Ewe Christians in Southeastern Ghana'. Journal of Religion in Africa 22.2, 98-132.

- 2004. 'Christianity in Africa: From African Independent to PentecostalCharismatic Churches'. Annual Review of Anthropology 33, 447-474.

Mhegera, Elias. 2011. 'Tanzania: It is claimed a cure for AID s has been found in Loliondo'. <http://www.nl-aid.org/continent/sub-saharan-africa/tanzania-it-is-claimed-acure-for-aids-has-been-found-in-loliondo/> Accessed 3 May 2013.

Milingo, Emmanuel. 1992. La chiesa degli spiriti è da condannare. Milano: Insieme con Gesù alleluia.

Mosoba, Tom. 2011. 'Untold story of Loliondo mystery'. The Citizen, 13 March. <http:// www.thecitizen.co.tz/sunday-citizen/40-sunday-citizen-news/9007-untold-storyof-loliondo-mystery.html $\geq$ Accessed 6 October 2011.

Munga, Anneth Nyagawa. 1998. Uamsho: A Theological Study of the Proclamation of the Revival Movement within the Evangelical Lutheran Church in Tanzania. Studia Theological Lundensia 54. Lund: Lund University Press.

Mwakalinga, Atufigwege. 2011. Unamtambuaje nabii? Dar es Salaam.

Mwanahalisi February-June 2011.

Namu, John-Allan. 2011. 'Kenya: On the Trail of the Loliondo Drink of Life'. Daily Nation, 24 March. <http://www.nation.co.ke/Features/DN2/On-the-trail-of-the-Loliondodrink-of-life-/-/95786o/1132222/-/item/o/-/6blkrgz/-/index.html> Accessed 3 May 2013 .

Nathan, Eliekana, S.N. Eliufoo, and Hilphe Salema. 1952. Wasonjo na jinsi walivyopelekewa injili. S.l.: Kanisa la Kilutheri la Tanganyika ya Kaskazini.

Nipashe February-June 2011.

Nkwame, Mark. 2012. "Loliondo Babu” prepares for comeback'. Daily News, 20 February. $<$ http://www.dailynews.co.tz/index.php/local-news/2079-loliondo-babu-preparesfor-comeback> Accessed 23 February 2012. 
Osanjo, Tom. 2011. 'Drink This Herbal Cup: Churches Debate Healing Power of Pastor's "Miracle Cure"'. Christianity Today October 1, 16.

Päivänsalo, Ville. 2014. 'Lutheran Perspectives on the Right to Health in a Global World, in Lutheran Identity and Political Theology'. In Carl-Henric Grenholm and Göran Gunner (eds.), Lutheran Identity and Political Theology. Eugene, or: Pickwick, 49-66. Parsalaw, Joseph Wilson. 1999. A History of the Lutheran Church, Diocese in the Arusha Region from 1904 to 1958. Makumira Publications 12. Erlangen: Erlanger Verlag für Mission und Ökumene.

Philemon, Lusekelo. 28 March 2011. 'Retired pastor suspends services to new patients'. <http://www.ippmedia.com/frontend/index.php?l=27474> Accessed 6 October 2011.

Radio Islam Malawi. 31 May 2011. "Tanzanian has said the Loliondo "wonder herb" is safe for use'. <http://radioislam.org.mw/latestnews/archives450> Accessed 6 October 2011.

Rai February-June 2011.

Raia mwema February-June 2011.

Ranger, Terence O. 1992. 'Godly Medicine: The Ambiguities of Medical Mission in Southeastern Tanzania, 1900-1945'. In Steven Feierman and John M. Janzen (eds.), The Social Basis of Health \& Healing in Africa. Berkeley and Los Angeles, CA: University of California Press, 256-282.

Risasi 2011 Machi 19-22. 'Babu Loliondo apata mshtuko' <http://www.globalpublishers. info/profiles/blogs/babu-loliondo-apata-mshtuko?xg_source=activity> Accessed 5 October 2011.

Sendoro, Elinaza E. 2000. Uamsho na Karama: Roho Mtakatifu Katika Makanisa ya Kihistoria Tanzania. Moshi: New Millennium Books.

Shout Africa. 3 May 2011. 'Tanzania: Loliondo Herbalist now fear [sic] for his life'. $<$ http://www.shout-africa.com/news/tanzania-loliondo-herbalist-now-fear-for-hislife/> Accessed 6 October 2011.

Smart African Travel. 19 March 2011. 'Is Loliondo emerging as Tanzania's medical \& spiritual tourism destination?' < http://www.smartafricantravel.com/blog/is-loliondoemerging-as-tanzania $\% E 2 \% 80 \% 99$ s-medical-spiritual-tourism-destination/> Accessed 6 October 2011.

Stroeken, Koen. 2010. Moral Power: The Magic of Witchcraft. New York: Berghahn Books. Swahili Street. 7 March 2011. ' "Destroy the old man of Loliondo!" '<http://swahilistreet. wordpress.com/2011/03/o7/destroy-the-old-man-of-loliondo/> Accessed 6 October 2011.

Tanzanian Affairs. 1 May 2011. 'The Loliondo Phenomenon'. <http://www.tzaffairs. org/2011/05/the-loliondo-phenomenon/> Accessed 6 October 2011.

Tanzanian People. 2011. 'About "Ambilikile Mwasapile" '< http://tanzanian-people. informationmart.net/Ambilikile_Mwasapile/item $>$ Accessed 6 October 2011. 
Thornton, John K. 1998. The Congolese Saint Anthony: Dona Beatriz Kimpa Vita and the Antonian Movement, 1684-1706. Cambridge: Cambridge University Press.

Ubwani, Zephania. 2011. 'Chartered aircraft firms increase flights to Loliondo'. Business Daily, 12 April. <http://www.businessdailyafrica.com/Corporate-News/Charteredaircraft-firms-increase-flights-to-Loliondo/-/539550/1142762/-/htxarpz/-/index. html $>$ Accessed 6 October 2011.

UNAIDS. 2012. Country Progress Reporting. http://www.unaids.org/sites/default/files/ en/dataanalysis/knowyourresponse/countryprogressreports/2012countries/ce_TZ_ Narrative_Report\%5B1\%5D.pdf Accessed 28 March 2015.

Vähäkangas, Auli. 2009. Christian Couples Coping with Childlessness: Narratives from Machame, Kilimanjaro. American Society of Missiology Monograph Series 4. Eugene, or: Pickwick Publications.

- 2011. 'Traditional, Christian and Modern Social Support for the HIV Positive of Tanzania'. Swedish Missiological Themes 99.1, 35-55.

- 2012. 'Contextual Pastoral Counseling among Terminally Ill AIDs Patients in Tanzania'. The Journal of Pastoral Theology 22.1, 6.1-6.14.

Vähäkangas, Mika. 2002. 'Pyhä Henki ja pahat henget: Tansanian luterilaisten suhtautuminen perinteiseen parantamiseen'. In Mari Pöntinen (ed.), Kohtaamisen haaste, näkökulmia kulttuurienväliseen vuoropuheluun. Helsinki: Suomen Lähetysseura, 120-141.

. 2008a. Between Ghambageu and Jesus: The Encounter between Sonjo Traditional Leaders and Missionary Christianity. Studia missiologica et oecumenica fennica 61. Helsinki: Luther-Agricola-Society.

- 2008b. 'Ghambageu Encounters Jesus in Sonjo Mythology: Syncretism as African Rational Action'. Journal of American Academy of Religion 76.1, 111-137.

Wavuti.com. 2011. Update: Tiba ya 'Mugariga' ya Mch. Mwasapile, Loliondo, 07/03/2011. 'Gazeti Wananchi linaripoti aliyoyasema Askofu Kakobe huhusu tiba hiyo'. <http:// www.wavuti.com/4/post/2011/o3/update-ya-tiba-ya-mugariga-ya-mch-mwasapileloliondo.html\#axzz2SDFmsRBm> Accessed 6 October 2011.

Wesangula, Daniel. 2011. 'Queues shorten as faith in Loliondo's drug wanes' Daily Nation, 27 August. <http://www.nation.co.ke/News/Queues-shorten-as-faith-in-Loliondosdrug-wanes-/-/1056/1226470/-/guo2so/-/index.html> Accessed 3 May 2013.

Wilkens, Katharina. 2009. 'Mary and the Demons: Marian Devotion and Ritual Healing in Tanzania'. Journal of Religion in Africa 39.1, 295-318.

- 2011. Holy Water and Evil Spirits: Religious Healing in East Africa. Beiträge zur Afrika-Forschung 47. Berlin: LIT Verlag.

Wijsen, Frans J.S. 1993. There is Only One God: A Social-Scientific and Theological Study of Popular Religion and Evangelization in Sukumaland, Northwest Tanzania. Kampen: Kok.

Wolanin, Adam. 1993. Alcuni aspetti della realtà religiosa africana: 'Chiese indipendenti' e teologia africana. Roma: Editrice Pontificia Università Gregoriana. 


\section{Notes}

* I I want to thank Drs. Päivi Hasu and Auli Vähäkangas from Helsinki University and Prof. Galia Sabar from Tel Aviv University as well as Aron Engberg and Hans Olsson from Lund University for feedback during the process of writing this article.

$1 \quad$ For a typology of medical pluralism see Janzen 2002, 234-235.

2 Concerning the searches, one needs to note that the name 'Ambilikile Mwasapila' was misspelled in many different ways.

3 Muslim healing is often counted in the category of traditional healing. It tends to overlap in terms of practices and theories with traditional medicine but it also has some, often Qur'an related, practices that are based on Muslim theological ideas, and that should not be indiscriminately lumped together with healing in the African traditional religions. See Wilkens 2011, 23-39 for details. Makanisa ya kiroho (Swahili for spiritual churches) is the common term used for all churches that concentrate on Charismatic phenomena in one way or another. Outsiders mostly label these churches Pentecostal, Neo-Pentecostal, or Charismatic, and yet some of them definitely better fit the group of African Instituted Churches. Because the classification of churches is difficult and the outside taxonomy quite imposing, I prefer to stick to the local classification. Spiritual churches should in no case be mixed with what in some parts of Africa are called spirit churches or churches of the spirit(s), referring to communities allegedly making pacts with evil spirits. See, e.g., Milingo 1992.

5 The Christian Fво share of Tanzanian health services varies between 20 and 40 percent, depending on the criteria. Muslim FBos also provide biomedical services, but to a lesser extent. Päivänsalo 2014.

6 For a discussion on medical pluralism in mission studies see, e.g., Huizer 1987; Jansen 2001.

7 There is no research covering the whole of mission history in the area. For a synopsis of available written information see Vähäkangas 2008a, 50-6o.

8 FD [fieldwork diary], 6, 52-informal communication; Rev. Philemon Mollel 2 February 2012; several ELCT pastors 6 February 2012; Babu 3, 10; Mwakalinga 2011, 2.

9 Mwakalinga 2011, 1; Babu 2, 4. Interestingly enough, Rev. Mwasapila's ethnic and denominational background is the same as that of one of the major Charismatic preachers, Christopher Mwakasege. The area they come from is interesting in terms of African Christianity because strong Christian and African traditional influences as well as Eastern, Central and Southern African elements encounter each other there, since Malawi, Mozambique, Zambia, and Congo are nearby.

10 'Mpe ile dawa yako atapona UKIMWI'. Babu 2. See also Mwakalinga 2011, 3. For a similar case of AIDS medicine received in a dream in a traditional healing context see Langwick 2011, 1-2.

11 E.g., Osanjo 2011. I visited one of the many graveyards for those who died while queuing; this one in the village contained fifteen graves. FD 33-35.

12 Mugariga is Swahili. Latin: Carissa spinarum or Carissa edulis. Malebo and Mbwambo 2011, 9 . 
13 Congolese revival leader Pastor Daniel Ndoundou is reported to have distributed divinely revealed herbal medicines as part of his extremely popular counselling ministry in the 1950s through the 1980s. Åhman 2013.

14 Babu 5, 1; Mwakalinga 2011, 7. The price was often simply mentioned in the media but it was also frequently commented on in relation to descriptions of Babu's modesty and uprightness. See, e.g., Mosoba 2011.

15 Babu kikombe, 17-18: 'Watu hawa wote Mungu wametoka mbali na kunifuata mimi. Wamekufuata wewe maana mahali hapa umeweka muujiza wako. Nakusihi sasa Mungu chukua magonjwa yao yote, watolee Bwana mzigo huu waende wakiwa wameanza maisha mapya.... Hakuna magonjwa yatakayo kubabaisha Mungu... Tena Mungu uliwaumba na mikono mitakatifu isiyokuwa na ugonjwa,magonjwa hayakutoka kwako yametoka kwa ibilisi na ushirikina na uchawi. Ninayakataa kwa mamlaka uliyonipa katika miili yao.... Asante maana umesikia maombi yetu... Ninaomba nikiamini utayatimiza hayo,kwa jina la Bwana wetu Yesu Kristo. Amen'.

16 Babu kikombe, 15: 'Na mimi nikamuuliza Mungu, akaniambia dawa hii wakiishakunywa inashika nafasi ya vile vidonge,sasa nasema hivi pia inategemea na imani yako. Ukiona imani yako ni haba endelea na vidonge'.

17 Here I owe gratitude to Makumira University College leadership, Professor Parsalaw, and Mr. Lekoringo for helping me through the process in the regional headquarters.

18 E.g., Majira 11 March 2011, 1, 4; Majira 16 March 2011, 1, 4; Majira 17 March 2011, 1, 4; Majira 25 March 2011, 4; Nipashe 15 March 2011, 1, 4; Nipashe 17 March 2011, 1, 4; Tanzanian Affairs 2011, 1 .

19 Auli Vähäkangas has conducted fieldwork among volunteers working with HIV+ people in the Arusha region, and this topic of Babu's patients giving up their ARVs and subsequently dying often came up spontaneously. The material is unpublished to date. Likewise, ancestors may decide about the fee of a traditional specialist. Green 2003, 128. Patients came to Babu even from the almost totally Muslim Zanzibar. Beckmann 2012, 702.

Feierman 2000, 325-326. Stroeken points out that for the Sukuma, the element (shangila) rendering the herb potent can also be material even though the point is in the symbolic function even in that case. Stroeken 2010, 1, 30, 121, 124, 242, 247-249.

'Kanyaga Babu wa Loliondo, sambaratisha babu wa Loliondo, kazi za babu saga'. Wavuti. com 2011.

24 For a similar discourse in Southern Tanzania, see Langwick 2011, 3-5.

25 Babu 3, 3: 'Walipotuma watu kuja kuchukua dawa ili kupima niliwaambia wataona vitu, lakini hawataona neno la Mungu. Kwa hiyo wao watakuwa wanahangaika na mti, Lakini neno la Mungu lililoko ndani hawataliona'.

26 This threefold division of cultural categories applies naturally to Christian Tanzanians. A significant portion of the Tanzanian population is Muslim, and it is questionable whether this kind of taxonomy would represent their thought were the concept kikristo replaced by kiislamu. Furthermore, the fact that in some areas Islam is a relatively recent arrival while in some coastal parts it has a millennium-long history may result in Muslim views on cultural encounters varying more than those of Christians. 
27 See Meyer 2004, 454-455 on how one should not simplify the position of mission churches and AICs vis-à-vis modernity and Africanness.

28 See Becker and Geissler 2009, 12-14 for a discussion on the multifaceted nature of the concept of modernity in Africa. What is noteworthy is that kisasa is an even more multifaceted concept than modernity.

29 Dilger (2009) hints toward this direction in the title of his article: 'Healing the Wounds of Modernity'. 